\title{
Can Mean Platelet Volume Value Be Used as Inflammation Marker in Children with Familial Mediterranean Fever?
}

\author{
Ailesel Akdeniz Ateşi Tanılı Çocuklarda Ortalama Trombosit Hacmi Değeri Enflamasyon \\ Belirteci Olarak Kullanılabilir mi?
}

\author{
(D) Erhan AYGÜN1², (D) Fatih Mehmet KELEŞOĞLU², (D) Rukiye ÖMEROĞLU EKER² \\ 1 istanbul University, Istanbul Faculty of Medicine, Department of Child Health and Diseases, Istanbul, Turkey \\ 2istanbul University, İstanbul Faculty of Medicine, Department of Child Health and Diseases, Division of Pediatric Rheumatology, Istanbul, Turkey
}

\begin{abstract}
Aim: Familial Mediterranean Fever (FMF) is disrupted response to inflammation by the organism as a result of mutations in the MEFV gene. It has been shown that the mean platelet volume could be used as a marker in many inflammatory diseases. In this study, it was aimed to determine inflammation by observing the changes in the mean platelet volume in the complete blood count.

Materials and Methods: The study included 570 children diagnosed with the FMF based on the Tel-Hashomer Criteria. We also included 73 healthy children as a control group. Demographic features, results of genetic analyses, complete blood count parameters, mean platelet volume levels, and C-reactive protein results were evaluated retrospectively. Data of the patients were recorded separately based on the acute attack and attack-free periods under treatment.

Results: The mean platelet volume was found to be $8.4 \pm 2.4 \mathrm{fL}$ in the attack period and $9.5 \pm 1.9 \mathrm{fL}$ in the attack-free period. The mean platelet volume was significantly lower in patients with an attack period compared to the patients at an attack-free period. Leukocyte count and C-reactive protein were statistically significantly higher in the attack period compared to the attack-free period.

Conclusion: The mean platelet volume decreases in patients with FMF with the effect of inflammation during the attack period. We think that it is important to consider mean platelet volume while evaluating the blood count.
\end{abstract}

Keywords: Familial Mediterranean Fever, inflammation, mean platelet volume

\section{ÖZ}

Amaç: Ailevi Akdeniz Ateşi (AAA), MEFV geninde meydana gelen mutasyonlar sonucu organizmanın enflamasyona verdiği yanıtın bozulmasıdır. Enflamatuvar hastalıkların pek çoğunda ortalama trombosit hacminin belirteç olarak kullanılabileceği gösterilmiştir. Bu çalışmada tam kan sayımındaki ortalama trombosit hacmindeki değişikliklere bakarak enflamasyonun belirlenmesi amaçlandı.

Gereç ve Yöntem: Çalışmaya Tel-Hashomer kriterlerine göre AAA tanısı almış 570 çocuk dahil edildi. Ayrıca 73 sağlıklı çocuk kontrol gurubu olarak dahil edildi. Hastaların demografik özellikleri, genetik tarama sonuçları, tam kan sayımı parametreleri, ortalama trombosit hacminin düzeyleri, C-reaktif protein değerleri retrospektif olarak değerlendirildi. Hastaların verileri tedavi altında ataklı ve ataksız dönemlerine göre ayrı ayrı kaydedildi.

Bulgular: Ortalama trombosit hacmi ataklı dönemde $8,4 \pm 2,4 \mathrm{fL}$ iken ataksız dönemde 9,5 $\pm 1,9 \mathrm{fL}$ olarak saptandı. Hastaların ataklı dönem ortalama trombosit hacminin düzeyleri, ataksız döneme göre istatistiksel olarak anlamlı düşüktü. Beyaz küre sayıları ve C-reaktif protein seviyeleri atak döneminde ataksız döneme göre istatistiksel olarak anlamlı yüksekti.

Sonuç: AAA tanılı hastalarda ortalama trombosit hacmi, enflamasyonun etkisiyle atak döneminde azalmaktadır. Kan sayımı sonucu değerlendirilirken ortalama trombosit hacminin değerinin de göz önünde bulundurulmasının önemli olduğunu düşünmekteyiz.

Anahtar Kelimeler: Ailevi Akdeniz Ateşi, enflamasyon, ortalama trombosit hacmi

Address for Correspondence: Erhan AYGÜN MD, İstanbul University, İstanbul Faculty of Medicine, Department of Child Health and Diseases, İstanbul, Turkey E-mail: dr.erhanaygun@gmail.com ORCID ID: orcid.org/0000-0002-4495-5824

Received: 15.08.2020 Accepted: 02.03.2021 


\section{INTRODUCTION}

Familial Mediterranean Fever (FMF) is an autosomal recessively inherited inflammatory disease characterized by short-term attacks of polyserositis accompanied by fever. It has been frequently described in communities of Mediterranean and Middle Eastern origin such as Turks, Armenians, Jews, and Arabs'. Finding the MEFV gene encoding the pyrin protein on the short arm of the sixteenth chromosome has revealed that the clinical course of the disease occurs due to the inability to suppress inflammation ${ }^{2,3}$. It has been found that acute inflammatory markers such as $\mathrm{C}$-reactive protein (CRP), sedimentation, serum amyloid A, interleukin-2 (IL), IL-6, IL-8 and tumor necrosis factor-alpha (TNF- $\alpha$ ) levels are high during FMF attack periods ${ }^{4,5}$. Moreover, it has also been reported that the inflammatory process continues in attack-free periods ${ }^{6}$. Mean platelet volume (MPV) is an inexpensive laboratory value that shows the MPV routinely measured in the complete blood count and shows platelet function and activation ${ }^{7}$. Large platelets are functionally, metabolically and enzymatically more active than small ones ${ }^{8}$.

In the literature, it has been reported that MPV has an important role as an inflammation marker and can be used as a marker for the activity of the disease in chronic inflammatory diseases ${ }^{9-13}$. There are studies evaluating MPV in patients with FMF, but conflicting results have been reported.

In this study, it was aimed to determine inflammation by evaluating changes in MPV in complete blood count, which is a simple test in pediatric FMF patients.

\section{MATERIALS AND METHODS}

We retrospectively analyzed 570 patients who were diagnosed with FMF according to the Tel-Hashomer Criteria and followed up at regular intervals in the Pediatric Rheumatology Outpatient Clinic between 2014 and 2016. Mutation results were recorded. The patients were divided into two groups: The attack group (those with active clinical symptoms and CRP $>10 \mathrm{mg} / \mathrm{L}$ ) and the attack-free group. In addition, 73 cases who applied to the pediatric outpatient clinic and did not have inflammatory findings were included as the control group. Cases without mutation analysis results and clinical data or those who were treated with anakinra were not included in the study.

As laboratory parameters, white blood cell, platelet counts, MPV, and CRP levels were recorded. The examinations performed during the attack and non-attack periods were recorded separately. Complete blood count was studied in automatic cell counting devices (LH 780 Beckman Coulter) with blood samples taken into tubes containing dipotassium ethylenediamine tetraacetic acid (EDTA). CRP titers were analyzed on Beckman-Coulter DXC 800 brand devices in our laboratory using standard analyzers.
Our study was carried out in accordance with the principles of the Declaration of Helsinki. Research and publication ethics were complied with. Approval was obtained from the Ethics Committee of İstanbul University in March 2016 with the ethics number of 2016/363.

\section{Statistical Analysis}

As descriptive statistics, mean and standard deviation for numerical variables and number and percentage values for categorical variables were given. While the significance test of the difference between the two means was used in group comparison for numerical variables, the chi-square test was used for categorical variables. The Student's t-test was used to compare continuous data. To compare 3 groups in this study, one-way ANOVA followed by post-hoc Bonferroni test was performed in statistical analysis. Analyses were obtained using the Statistical Package for the Social Sciences v.21 software. The significance level was taken as $p<0.05$.

\section{RESULTS}

A total of 570 FMF patients and 73 healthy cases were included in the study. The attack group consisted of 33 boys (54\%) and 28 girls (46\%), the non-attack group included 239 boys (47\%) and 270 girls (53\%), and the control group consisted of 34 boys $(47 \%)$ and 39 girls (53\%). The mean age was $9.8 \pm 4.63$ years in the FMF attack group, $11.2 \pm 4.46$ years in the attack-free group, and $10.4 \pm 5.8$ years in the control group. All patients included in the study were receiving colchicine treatment. One or more mutations were detected in a total of $527(91.9 \%)$ patients. The frequency of mutations was $16.8 \%$ for M694V

\section{Table 1. Mutation types}

\begin{tabular}{|l|l|}
\hline Mutation type & $\begin{array}{l}\text { Number of } \\
\text { patients }\end{array}$ \\
\hline M694V heterozygous & $89(16.8 \%)$ \\
\hline E1480 heterozygous & $65(12.3 \%)$ \\
\hline M694V homozygous & $59(11.2 \%)$ \\
\hline R2020 heterozygous & $55(10.4 \%)$ \\
\hline M680I heterozygous & $30(5.7 \%)$ \\
\hline M680I/M694V compound heterozygous & $27(5.1 \%)$ \\
\hline R2020/M694V compound heterozygous & $24(4.5 \%)$ \\
\hline V726A heterozygous & $22(4.1 \%)$ \\
\hline V726A/M694V compound heterozygous & $16(3 \%)$ \\
\hline R2020 homozygous & $13(2.4 \%)$ \\
\hline R2020/M694V homozygous & $12(2.1 \%)$ \\
\hline E1480/M684V compound heterozygous & $11(2 \%)$ \\
\hline E1480/R2020 compound heterozygous & $9(1.7 \%)$ \\
\hline M680I/R2020 homozygous & $8(1.5 \%)$ \\
\hline Patients found to have other mutations & $87(16.5 \%)$ \\
\hline Total & $527(91.9 \%)$ \\
\hline
\end{tabular}


heterozygosity as the most common mutation, followed by 12.3\% for E1480, 11.2\% for M694V homozygosity, 10.4\% for R2020 heterozygosity, and 5.7\% for M6801 G/C heterozygosity. These groups were also categorized for specific mutations in Table 1. There was no significant difference between the groups in terms of age and gender. Groups were divided according to clinical attack status and mutation types. The mean followup time was $4.1 \pm 2.5$ years, and the mean disease onset was $8.2 \pm 3.99$ years. Sixty-one patients were in the attack period and 509 patients were in the attack-free period. All groups were evaluated in terms of CRP and leukocyte values. CRP and leukocyte levels were found to be significantly higher in the FMF attack group compared to the non-attack group and control group. The MPV value was found to be lower in the attack period compared to the attack-free and control period. There was no difference between the attack-free group and the control group in terms of MPV, CRP and leukocyte values. Each group is summarized in Table 2.

\section{DISCUSSION}

In our study, the mean MPV value was found to be lower in the attack period compared to the attack-free period.

Platelet activation is associated with increased atherosclerotic risk. MPV is an easily accessible and cost-effective test that can show platelet activation and function ${ }^{14}$. In a small number of studies comparing MPV values at the time of attack and in attack-free period in children with FMF, it was reported that there was no significant difference ${ }^{15-18}$. In the literature, there are studies in which MPV is significantly higher in FMF patients during attack-free periods ${ }^{17,18}$. On the contrary, there are also studies showing that platelet counts are significantly higher and MPV values are significantly lower during attacks in chronic diseases compared to control groups, 6 ,19-21.

In our study, MPV values were significantly lower in patients in the attack period compared to the control group. Changes in the microtubular structure of platelets are thought to reduce the MPV value by changing the platelet shape during inflammation. In addition, a relative decrease in MPV in the circulation can be observed with the migration of large platelets to the area of inflammation ${ }^{12}$. Therefore, we concluded that the low MPV that we detected during an attack of FMF in our study might be useful to show episodes of attacks in FMF.

The use of colchicine may suppress platelet activation ${ }^{22-24}$. All of our patients were receiving colchicine treatment. This may partly explain the non-significant difference in MPV values between the attack-free group and healthy controls.

In the literature, studies comparing the CRP values of patients in the attack-free period and the control group have reported a significant increase in CRP value. However, it is seen that the sample size of these studies is not sufficient ${ }^{22,25}$. The strengths of our study are the size of sample in which each group included a sufficient number of subjects and the inclusion of an attackfree group with negative CRP values. Özer et al. ${ }^{25}$ stated in their study that inflammation was higher in the attack-free period than the control group. However, in their study, FMF patients had higher CRP values in the attack-free period compared to the control group. Although it was stated that the patient group included in their study was in the attack-free period, the significant increase in CRP values in the FMF group should be considered as the weak point of the study. In our study, similar to the studies in the literature, elevated CRP and white blood cell were found at the time of attack. CRP values were normal in the attack-free period and in the control group. We thought that these results were related to the inflammation during the attack. It was observed that the incidence of amyloidosis was higher in the M694V genotype in the patient followed up with the diagnosis of Familial Mediterranean Fever. In addition, the incidence of arthritis and severe disease was found to be higher in M694V homozygous patients ${ }^{26}$. None of our patients had amyloidosis.

\section{Study Limitations}

The major limitations of our study are that it was performed in a single center, patients were on colchicine treatment, which can reduce inflammation, and it had a retrospective design. Other important limitations are that the personnel performing

Table 2. Comparison of the attack group, the attack-free group and the control group

\begin{tabular}{|c|c|c|c|c|c|c|}
\hline & $\begin{array}{l}\text { Attack group } \\
\text { (Number of patients: 61) }\end{array}$ & $\begin{array}{l}\text { Attack-free group } \\
\text { (Number of patients: 509) }\end{array}$ & $\begin{array}{l}\text { Control group } \\
\text { (Number of patients: } 73 \text { ) }\end{array}$ & P1 & P2 & P3 \\
\hline Age (year) & 9.8 & 11.2 & 10.4 & 0.695 & 0.262 & 0.035 \\
\hline Girl (n) & 33 & 239 & 34 & & & \\
\hline Boy (n) & 28 & 270 & 39 & & & \\
\hline MPV (fL) & $8.4 \pm 2.4$ & $9.5 \pm 1.9$ & $9.6 \pm 1.1$ & $<0.001$ & $>0.05$ & $<0.001$ \\
\hline WBC $\left(/ \mathrm{mm}^{3}\right)$ & $11460 \pm 4650$ & $8460 \pm 2450$ & $7860 \pm 1850$ & $<0.001$ & $>0.05$ & $>0.05$ \\
\hline
\end{tabular}


the blood collection were different, and the technique of blood collection and the time it took to be taken to the laboratory were not known. In prospective studies to be conducted in newly diagnosed patients who do not use colchicine, monitorization of MPV changes before, during and after an attack will yield safer results.

\section{CONCLUSION}

We showed that MPV decreased with the effect of inflammation during the attack periods in patients with FMF. We think that it is important to consider the MPV value while evaluating the blood count result, which is cheap, easy and can be checked in every clinic. Considering the conflicting results of the studies in the literature, more comprehensive studies are required to increase the reliability of MPV in clinical applications and to ensure its effective clinical use.

\section{Ethics}

Ethics Committee Approval: Approval was obtained from the Ethics Committee of İstanbul University in March 2016 (protocol no: 2016/363).

Informed Consent: Retrospective study.

Peer-review: Externally peer-reviewed.

\section{Authorship Contributions}

Concept: E.A., F.M.K., R.Ö.E., Design: E.A., F.M.K., R.Ö.E., Data Collection or Processing: E.A., F.M.K., R.Ö.E., Analysis or Interpretation: E.A., F.M.K., R.Ö.E., Literature Search: E.A., F.M.K., Writing: E.A., F.M.K.

Conflict of Interest: No conflict of interest was declared by the authors.

Financial Disclosure: The authors declared that this study received no financial support.

\section{References}

1. Yavuz S, Duru NS, Elevli M. Ailevi Akdeniz Ateşi Hastalarında Klinik, Laboratuvar Bulguları, Hastalık Ağırlık Skorları ve Gen Mutasyonları Arasındaki İlişki. Med Bull Haseki. 2018;56:58-64.

2. Abuhandan M, Kaya C, Güzelçiçek A. Ailevi Akdeniz ateşi tanısı alan 186 olgunun klinik semptom ve MEFV geni mutasyonlarının incelenmesi. Dicle Tıp Derg. 2015;42:61-5.

3. Battal F, Silan F, Topaloğlu N, Aylanç H, Yıldırım Ş. Binnetoğlu FK, et al. The MEFV gene pathogenic variants and phenotype-genotype correlation in children with familial Mediterranean fever in the Çanakkale population. Balkan J Med Genet. 2017;19:23-8.

4. Baykal Y, Saglam K, Yılmaz, Taşlıpınar A, Akıncı SB, İnal A. Serum IL-2, IL6, IL-10, TNF $\alpha$ level in familial mediterranean fever patients. Clin Rheumatol. $2003 ; 22: 99-101$

5. Keleşoğlu FM, Aygün E, Okumuş NK, Ersoy A, Karapınar E, Sağlam $\mathrm{N}$, et al. Ailesel Akdeniz ateşi hastalarında subklinik inflamasyonun değerlendirilmesi: mutasyon tipleri ve atak durumu ile ilişkiler: retrospektif bir çalışma. Klinik Romatol. 2016;35:2757-63.

6. Doğruel D, Ekinci RMK, Balcı S, Yılmaz M, Altıntaş DU. Ailevi Akdeniz Ateşi Olan Çocuklarda Ortalama Trombosit Hacminin Klinik Önemi. ACU Sağlık Bil Derg. 2019;4:589-92.
7. Karagoz I, Aktas G, Yoldas H, Yildiz I, Ogun MN, Bilgi M, et al. Association Between Hemogram Parameters and Survival of Critically III Patients. J Intensive Care Med. 2019;34:511-3.

8. Kim $\mathrm{CH}$, Kim SJ, Lee MJ, Kwon YE, Kim YL, Park KS, et al. An increase in mean platelet volume from baseline is associated with mortality in patients with severe sepsis or septic shock. PLoS One. 2015;10:e0119437.

9. Taşoğlu Ö, Bölük H, Şahin Onat Ş, Taşoğlu I, Özgirgin N. Is blood neutrophillymphocyte ratio an independent predictor of knee osteoarthritis severity? Clin Rheumatol. 2016;35:1579-83.

10. Purnak T, Efe C, Yuksel O, Beyazit Y, Ozaslan E, Altiparmak E. Mean platelet volume could be a promising biomarker to monitor dietary compliance in celiac disease. Ups J Med Sci. 2011;116:208-11.

11. Beyazit Y, Sayilir A, Torun S, Suvak B, Yesil Y, Purnak T, et al. Mean platelet volume as an indicator of disease severity in patients with acute pancreatitis. Clin Res Hepatol Gastroenterol. 2012;36:162-8.

12. Gasparyan AY, Sandoo A, Stavropoulos-Kalinoglou A, Kitas GD. Mean platelet volume in patients with rheumatoid arthritis: the effect of antiTNF- $\alpha$ therapy. Rheumatol Int. 2010;30:1125-9.

13. Verma R, Mahapatro S, Kumar A, Rizvi I, Garg RK, Malhotra HS, et al Platelet dysfunction and coagulation assessment in patients of tuberculous meningitis. Neurol Sci. 2020;41:2103-10.

14. Uluca Ü, Ece A, Şen V, Karabel D, Yel S, Güneş A, et al. Usefulness of mean platelet volume and neutrophil-to-lymphocyte ratio for evaluation of children with Familial Mediterranean fever. Med Sci Monit. 2014;20:1578-82.

15. Basaran O, Uncu N, Celikel BA, Aydın F, Cakar N. Assessment of neutrophil to Iymphocyte ratio and mean platelet volume in pediatric familial Mediterranean fever patients. J Res Med Sci. 2017;22:35.

16. Ustun N, Ulaşlı AM, Çelik T, Yula E, Turhanoğlu AD. Mean Platelet Volume in Children with Familial Mediterranean Fever and the Relationship with Attack Status, Colchicine Treatment and Gene Mutation. Eur J Gen Med. 2014;11:169-73.

17. Sakallı H, Kal O. Mean platelet volume as a potential predictor of proteinuria and amyloidosis in familial Mediterranean fever. Clin Rheumatol. 2013;32:1185-90.

18. Hu ZD, Chen Y, Zhang L, Sun Y, Huang YL, Wang Q0, Xu YL, et al. Red blood cell distribution width is a potential index to assess the disease activity of systemic lupus erythematosus. Clin Chim Acta. 2013;425:202-5.

19. Sert A, Aypar E, Odabas D. Mean platelet volume in acute rheumatic fever. Platelets. 2013;24:378-82.

20. Zareifar S, Farahmand Far MR, Golfeshan F, Cohan N. Changes in platelet count and mean platelet volume during infectious and inflammatory disease and their correlation with ESR and CRP. J Clin Lab Anal. 2014;28:245-8.

21. Naghipour Hamzekolaei $M$, Jafarisani $M$, Farajzadeh $A$, Aghayan SS Atashi $\mathrm{A}$, Yarmohammadi $\mathrm{M}$, et al. Changes in mean platelet volume and hematologic indices in patients with panic disorder due to oxidative stress. Brain Behav. 2020;10:e01569.

22. Uslu AU, Deveci K, Korkmaz S, Aydin B, Senel S, Sancakdar E, et al. Is neutrophil/lymphocyte ratio associated with subclinical inflammation and amyloidosis in patients with familial Mediterranean fever? Biomed Res Int. 2013;2013:185317.

23. Menche D, Israel A, Karpatkin S. Platelets and microtubules. Effect of colchicine and D20 on platelet aggregation and release induced by calcium ionophore A23187. J Clin Invest. 1980;66:284-91.

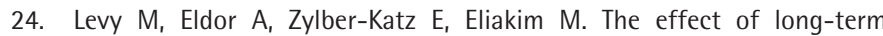
colchicine therapy in patients with recurrent polyserositis on the capacity of blood platelets to synthesize thromboxane $\mathrm{A} 2$. Br J Clin Pharmacol. 1983;16:191-4.

25. Özer S, Yılmaz R, Sönmezgöz E, Karaaslan E, Taşkın S, Bütün I, et al Simple markers for subclinical inflammation in patients with Familial Mediterranean Fever. Med Sci Monit. 2015;21:298-303.

26. Çağlar A, Özçelik G. Ailevi Akdeniz ateşi olan çocuklarda genotip-fenotip ilişkisi. İzmir Dr. Behçet Uz Çocuk Hast Dergisi. 2018;8:144-50. 